\title{
AUDIT SISTEM INFORMASI PADA BUS AKDP PUSPA JAYA
}

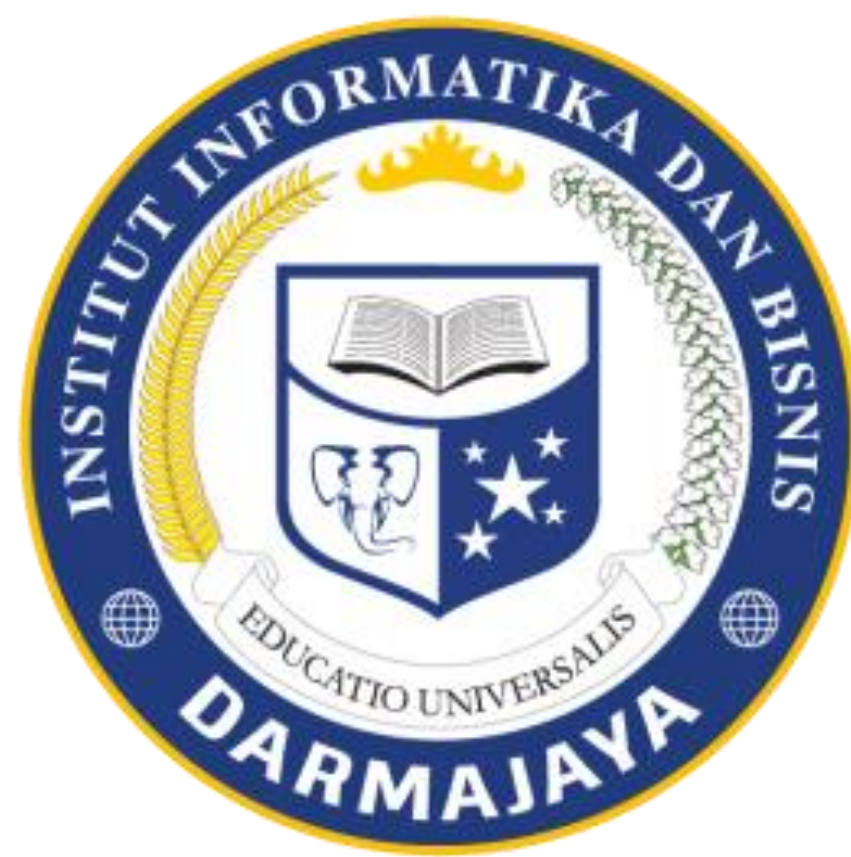

Disusun Oleh :

$$
\begin{aligned}
& \text { Nama : Syarif Maulana } \\
& \text { NPM : 1611058010P } \\
& \text { Kelas : P3 } \\
& \text { Matkul : AUDIT }
\end{aligned}
$$




\section{BAB I}

\section{Pendahuluan}

\subsection{Latar Belakang}

Tingginya permintaan masyarakat akan sarana transportasi di Sumatra selatan khususnya Lampung membuat para prusahaan Otobus beramai-ramai membuka trayek dari satu kota ke kota lainya. Salah satunya adalah prusahaan otobus Puspa Jaya yang namanya sudah banyak di kenal oleh masyarakat Lampung maupun luar lampung. Khususnya bagian divisi Bus AKDP yang memiliki trayek sputaran kota di Provinsi Lampung.

PO Puspa Jaya adalah perusahaan yang bergerak di bidang jasa transportasi darat yaitu bus. Terdapat banyak terayek baik trayek dalam kota maupun trayek antar provinsi.

\subsection{Sejarah}

\section{Sejarah PO Puspa Jaya :}

Perusahaan otobus (PO) yang ikut mendominasi bus trayek menyebrangi Selat Sunda adalah PO Puspa Jaya. PO Puspa Jaya yang berasal dari Lampung ini di dirikan oleh seorang transmigrasi asal Bali, ia adalah bapak I Ketut Narya yang memulai tanggak sejarah PO Puspa Jaya pada 31 Oktober 1980.

Di awal pendiriannya perusahaan keluarga ini, bapak I Ketut Narya hanya bermodalkan satu unit busa saja untuk melayani trayek Banjit - Tanjung Karang. Setelah berjalan dan mendapatkan tanggapan positif dari masyarakat Lampung, bus inipun mengembangkan trayek keluar provinsi atas permintaan para transmigran asal Bali di Lampung. Akhirnya pada tahun 1989 prusahaan ini membuka trayek ke Lampung - Denpasar.

Pada tahun 1992, kepemimpinan perusahaan ini diserahkan kepada bapak Ketut Pasek anak dari bapak Ketut Narya. Dari tahun 1992 bapak Ketut Pasek masih memimpin perusahaan otobus Puspa Jaya sampai sekarang. 


\section{BAB II}

\section{Tinjauan Pustaka}

\subsection{Pengertian Cobit}

Cobit adalah pemeriksaan yang dilakukan secarakritis dan sistematis oleh pihak yang independen, terhadap laporan keuangan yang telah disusun oleh manajemen beserta catatancatatan pembukuan danbukti-bukti pendukungnya, dengan tujuan untuk dapat memberikan pendapat mengenai kewajaran laporan keuangan tersebut (Sukrisno Agoes, 2007)

Cobit adalah suatu proses pengumpulan dan pengevaluasian Bahan bukti tentang informasi yang dapat diukur mengenai suatu entitas ekonomi yang dilakukan seorang yang kompeten dan independen untuk dapat menentukan dan melaporkan kesesuaian informasi dengan kriteria-kriteria yang telah ditetapkan. Auditing seharusnya dilakukan oleh seorang yang independent dan kompeten (Arensdan Loebbecke, 2003)

Control Objecttive for Information \& Related Technology (COBIT) adalah sekumpulan dokumentasi best practice untuk IT Governance yang dapat membantu auditor, pengguna (user), dan manajemen, untuk menjembatani gap antara resiko bisnis, kebutuhan control dan masalah-masalah teknis IT (Sasongko, 2009)

COBIT mendukung tata kelola TI dengan menyediakan kerangka kerja untuk mengatur keselarasan TI dengan bisnis. Selain itu, kerangka kerja juga memastikan bahwa TI memungkinkan bisnis, memaksimalkan keuntungan, resiko TI dikelola secara tepat, dan sumber daya TI digunakan secara bertanggungjawab.(Tanuwijaya dan Sarno, 2010)

\subsection{Pengertian Transportasi}

Pengertian transportasi menurut Morlok (1978) adalah kegiatan memindahkan atau mengangkut sesuatu dari satu tempat ketempat lain. Menurut Bowersox (1981), transportasi adalah perpindahan barang atau penunpang dari satu tempat ketempat lain, dimana produk dipindahkan ke tempat lain, dimana produk dipindahkan ke tempat tujuan dibutuhkan. Menurut Steenbrink (1974), transportasi didefinisikan sebagai perpindahan orang dan atau barabg dengan menggunakan kendaraan atau alat lain dari dan ketempat-tempat yang terpisah secara geografis. Secara umum dapat disimpulkan transportasi adalah suatu kegiatan memindahkan sesuatu (orangdan atau barang) dari satu tempat ke tempat lain, baik dengan atau tanpa sarana. 


\subsection{Pengertian Bus}

Menurut Kamus Besar Bahasa Indonesia mobil bus adalah setiap kendaraan bermotor yang dilengkapi dengan tempat duduk untuk lebih dari 8 (delapan) orang, tidak termasuk tempat duduk untuk pengemudi baik dilengkapi atau tidak dilengkapi dengan bagasi. Istilah bus berasal dari bahasa latin Omnibus, yang berarti "Kendaraan yang berhenti di semua perhentian". Pada awalnya, bus merupakan kendaraan yang di tarik kuda, kemudian dimulai dari tahun 1830-an bus bertenaga uap mulai ada. Seiring perkembangan zaman, bus bertenaga mesin pertama muncul bersamaan dengan perkembangan mobil. Setelah bus bertenaga mesin pertama pada tahun 1895, berbagai model dikembangkan pada tahun 1900- an, sampai akhirnya tersebar luas bentuk bus yang utuh mulai dari tahun 1950-an. Bus menjadi populer pada awal abad ke-20 karena Perang Dunia I dimana itu sangat diperlukan alat transportasi lain yang dapat mengangkut banyak penumpang. Di Indonesia klasifikasi bus umum dibagi ke dalam berbagai kategori, diantaranya berdasarkan jenis ada jenis bus berdasarkan ukuran, bus besar, bus sedang, dan bus kecil. Ada pula bus Antar Kota Antar Provinsi atau yang dikenal dengan sebutan AKAP. Bus AKAP adalah angkutan dari satu kota ke kota lain yang melalui antar daerah kabupaten/kota yang melalui lebih dari satu daerah provinsi dengan menggunakan mobil bus umum yang terikat dalam trayek 


\section{BAB III}

\section{Pembahasan}

\subsection{Wawancara}

Nara Sumber yang di wawancarai :

Nama : Wayan Wirna S.E

Jabatan : Wakil Direktur PO Puspa Jaya \& Kepala Oprasional AKAP

Alamat : Jl. Kamboja Labuan Dalem

Agama : Hindu

Hasil dari wawancara :

Struktur Organisasi Perusahaan PO Puspa Jaya

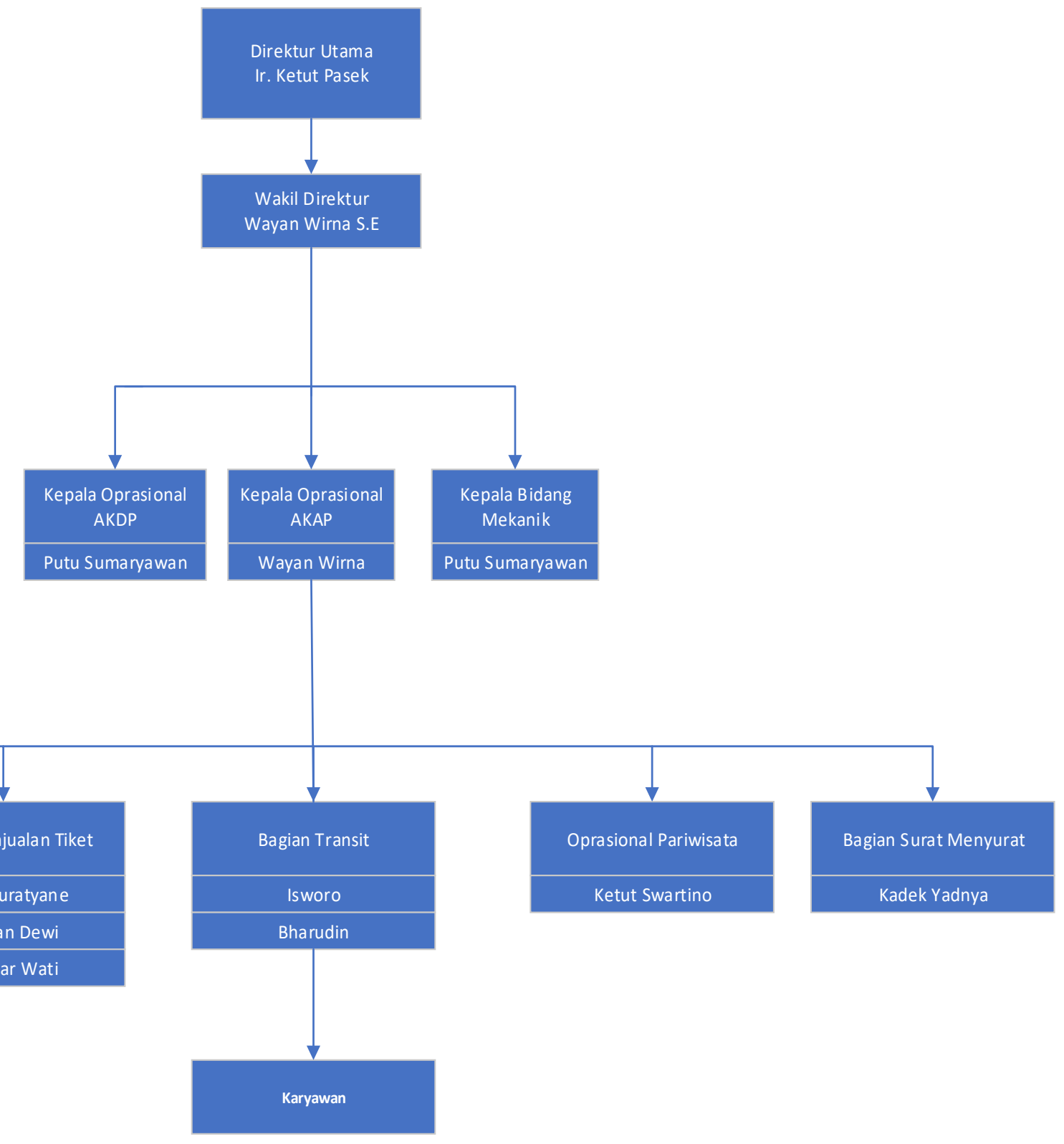


Visi \& Misi PO Puspa Jaya

Visi :

- Menjadi perusahaan transmigrasi yang unggul dalam pelayanan, karna kepuasan pelanggan adalah prioritas kami.

Misi :

- Memberikan pelayanan yang sebaik-baiknya dengan penuh rasa kekeluargaan.

- Menyediakan transportasi yang aman, nyaman, bersih, serta terjangkau.

- Memberikan pelayanan yang prima demi kepuasan pelanggan di dukung oleh sumberdaya yang berkualitas.

Penghargaan yang pernah diraih PO Puspa Jaya :

1. Juara 1 Terbaik Purusahaan otobus AKDP Provinsi Lampung

2. Penghargaan mentri perhubungan Perusahaan Angkutan Antar Kota Antar Provinsi

(AKAP) Dengan pelayanan Non Ekonomi terbaik tahun 2013

Pengaruh Terhadap Lingkungan :

Banyak manfaat bagi pedagang dilingkungan PO Puspa Jaya, jadi banyak pedangan yang berdagang di lingkungan puspa jaya, serta membuka lapangan kerja bagi warga sekitar lingkungan puspa jaya.

Nara Sumber yang di wawancarai :

Nama : Putu Sumaryawan

Jabatan : Kepala Oprasional AKDP \& Kepala Bidang Mekanik

Agama : Hindu

Hasil Wawancara : 
Struktur Divisi Bus Antar Kota Dalam Provinsi

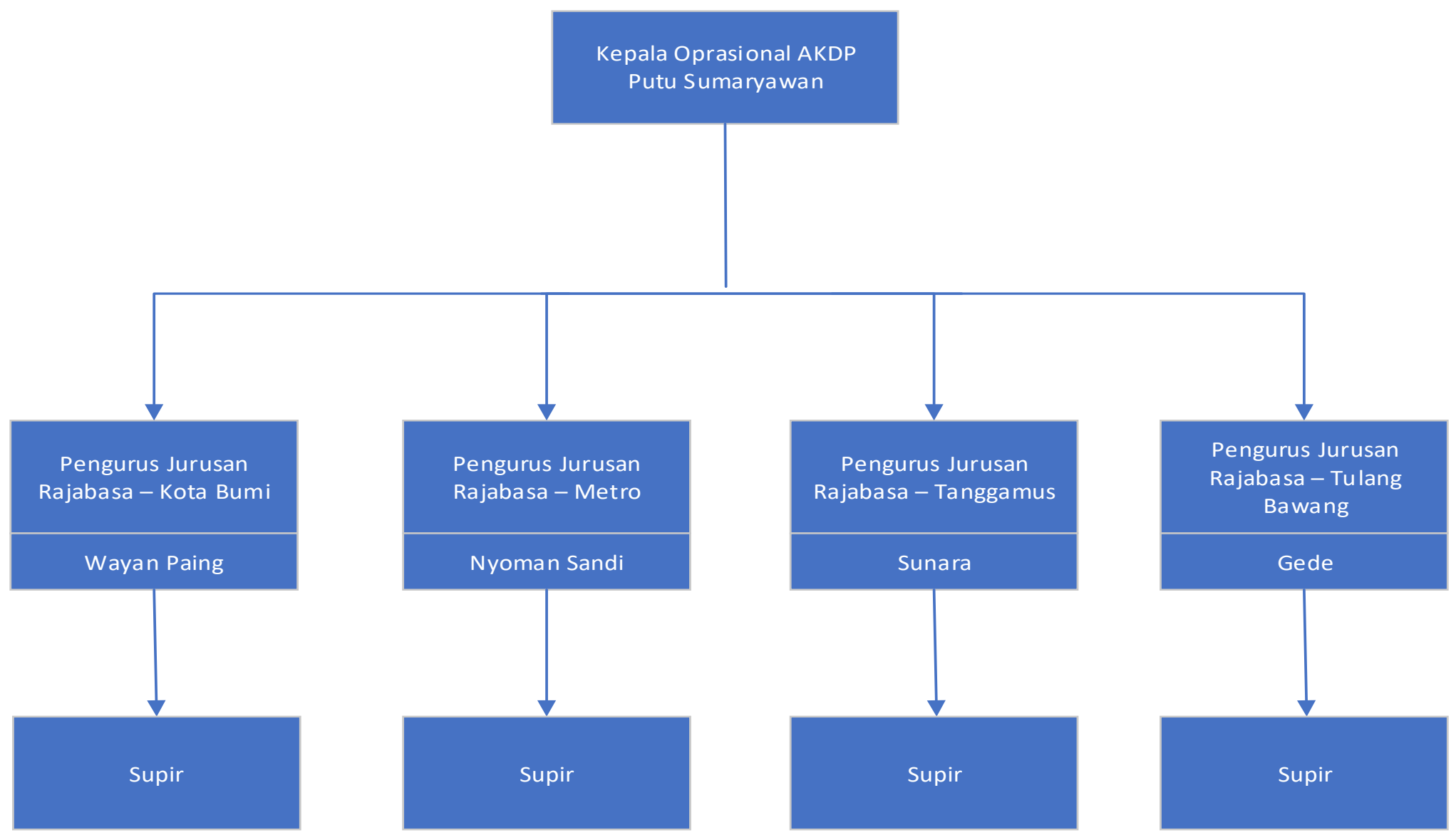




\subsection{Quisioner}

\section{KUESIONER BUS ANTAR KOTA PUSPA JAYA}

(Kuisioner Manajemen)

Keterangan Pilihan Jawaban :
SB : SB : SANGAT BAIK
C: CUKUP
STB : SANGAT TIDAK BAIK

B : BAIK TB: TIDAK BAIK

\begin{tabular}{|c|c|c|c|c|c|c|c|c|c|c|c|}
\hline \multirow[t]{2}{*}{ No } & \multirow[t]{2}{*}{ Pernyataan } & \multicolumn{5}{|c|}{ Performance } & \multicolumn{5}{|c|}{ Expectasi } \\
\hline & & SB & $\mathrm{B}$ & $\mathrm{C}$ & TB & STB & SB & $\mathrm{B}$ & C & TB & STB \\
\hline \multicolumn{12}{|c|}{ DS 1 Mendefinisikan Dan Mengelola Tingkat Jasa } \\
\hline \multicolumn{12}{|c|}{ DS 1.1 Rangka Pengelolaan Tingkat Jasa } \\
\hline 1 & $\begin{array}{l}\text { Bagaimana rangka pengelolaan struktur } \\
\text { organisasi pada bus antar kota }\end{array}$ & & & & & & & & & & \\
\hline 2 & $\begin{array}{l}\text { Bagaimana pengelolaan peran, dan tugas } \\
\text { pada bus antar kota }\end{array}$ & & & & & & & & & & \\
\hline \multicolumn{12}{|c|}{ DS 1.2 Ketentuan Jasa } \\
\hline 1 & $\begin{array}{l}\text { Bagaimana ketentuan jasa IT dan } \\
\text { persaratan bisnis pada bus antar kota }\end{array}$ & & & & & & & & & & \\
\hline 2 & $\begin{array}{l}\text { Pihak bus antar kota mendasari } \\
\text { pelayanan yang berkarakter dan } \\
\text { memenuhi persaratan }\end{array}$ & & & & & & & & & & \\
\hline \multicolumn{12}{|c|}{ DS 1.3 Kesepakatan Tingkat Jasa (SLA) } \\
\hline 1 & $\begin{array}{l}\text { Bagaimana kesepakatan komitment } \\
\text { pelanggan dengan bus antar kota }\end{array}$ & & & & & & & & & & \\
\hline 2 & $\begin{array}{l}\text { Bagaimana peran, dan tanggung jawab } \\
\text { kesepakatan jasa bus antar kota } \\
\text { terhadap pelanggan }\end{array}$ & & & & & & & & & & \\
\hline \multicolumn{12}{|c|}{ DS 1.4 Kesepakatan Tingkat Pengoprasian (OLA) } \\
\hline 1 & $\begin{array}{l}\text { Bagaimana kesepakatan oprasional bus } \\
\text { antar kota terhadap pelanggan }\end{array}$ & & & & & & & & & & \\
\hline 2 & $\begin{array}{l}\text { Proses-proses pada layanan sudah di } \\
\text { sosialisasikan dengan jelas }\end{array}$ & & & & & & & & & & \\
\hline \multicolumn{12}{|c|}{ DS 1.5 Pemantauan dan Pelaporan Pencapaian SLA } \\
\hline 1 & $\begin{array}{l}\text { Bagaimana manajemen melakukan } \\
\text { pemantauan terhadap bus antar kota }\end{array}$ & & & & & & & & & & \\
\hline 2 & $\begin{array}{l}\text { Bagaimana proses pemantauan dan } \\
\text { analisa manajemen terhadap jasa } \\
\text { individu bus antar kota }\end{array}$ & & & & & & & & & & \\
\hline \multicolumn{12}{|c|}{ DS 1.6 Ulasan SLA dan Kontraknya } \\
\hline 1 & $\begin{array}{l}\text { Bagaimana bus antar kota memberikan } \\
\text { pelayanan yang sesuai dengan yang di } \\
\text { janjikan }\end{array}$ & & & & & & & & & & \\
\hline 2 & $\begin{array}{l}\text { Bus antar kota memenuhi semua yang di } \\
\text { paparkan saat perjanjian }\end{array}$ & & & & & & & & & & \\
\hline
\end{tabular}




\begin{tabular}{|c|c|c|c|c|c|c|c|c|c|c|c|}
\hline \multirow[t]{2}{*}{ No } & \multirow[t]{2}{*}{ Pernyataan } & \multicolumn{5}{|c|}{ Performance } & \multicolumn{5}{|c|}{ Expectasi } \\
\hline & & SB & B & C & TB & STB & SB & B & $\mathrm{C}$ & TB & STB \\
\hline \multirow{2}{*}{\multicolumn{12}{|c|}{ ME 1 Mengawasi DAN MENGEVALUASI KINERJA IT }} \\
\hline & & & & & & & & & & & ME 1.1 Pendekatan Pemantauan \\
\hline 1 & $\begin{array}{l}\text { Bagaimana proses pemantauan bus antar } \\
\text { kota }\end{array}$ & & & & & & & & & & \\
\hline 2 & $\begin{array}{l}\text { Bagaimana pengawasan kontribusi IT } \\
\text { terhadap bus antar kota }\end{array}$ & & & & & & & & & & \\
\hline \multicolumn{12}{|c|}{ ME 1.2 Ketentuan dan kumpulan dari pemantauan data } \\
\hline 1 & $\begin{array}{l}\text { Bagaimana standar kinerja dalam bus } \\
\text { antar kota }\end{array}$ & & & & & & & & & & \\
\hline 2 & $\begin{array}{l}\text { Pemantauan perkembangan bus antar } \\
\text { kota di puspa jaya berjalan dengan baik }\end{array}$ & & & & & & & & & & \\
\hline \multicolumn{12}{|c|}{ ME 1.3 Metode Pemantauan } \\
\hline 1 & Metode yang diterapkan bus antar kota & & & & & & & & & & \\
\hline 2 & $\begin{array}{l}\text { Apakah Sistem yang berjalan dalam bus } \\
\text { antar kota sudah berjalan dengan baik }\end{array}$ & & & & & & & & & & \\
\hline \multicolumn{12}{|c|}{ ME 1.4 Pemeriksaan Kinerja } \\
\hline 1 & $\begin{array}{l}\text { Perbaikan Kinerja dalam bus antar kota } \\
\text { sudah dilakukan dengan baik }\end{array}$ & & & & & & & & & & \\
\hline 2 & $\begin{array}{l}\text { Pengecekan kinerja dalam bus antar kota } \\
\text { sudah berjalan dengan baik }\end{array}$ & & & & & & & & & & \\
\hline \multicolumn{12}{|c|}{ ME 1.5 Pelaporan Dewan dan Eksekutif } \\
\hline 1 & $\begin{array}{l}\text { Bagaimana laporan manajemen IT } \\
\text { terhadap tujuan yang telah tercapai }\end{array}$ & & & & & & & & & & \\
\hline 2 & $\begin{array}{l}\text { Laporan manajemen IT terhadap } \\
\text { anggaran yang digunakan serta kinerja } \\
\text { yang diraih }\end{array}$ & & & & & & & & & & \\
\hline \multicolumn{12}{|c|}{ ME 1.6 Tindakan Perbaikan } \\
\hline 1 & $\begin{array}{l}\text { Bagaimana pemantauan perbaikan } \\
\text { terhadap divisi bus antar kota }\end{array}$ & & & & & & & & & & \\
\hline 2 & $\begin{array}{l}\text { Bagaimana tindakan maintenance di } \\
\text { divisi bus antar kota }\end{array}$ & & & & & & & & & & \\
\hline
\end{tabular}




\section{KUESIONER BUS ANTAR KOTA PUSPA JAYA}

\section{(Kuisioner User)}

Keterangan Pilihan Jawaban :
SB : SB : SANGAT BAIK
C : CUKUP
STB : SANGAT TIDAK BAIK

B : BAIK

TB: TIDAK BAIK

\begin{tabular}{|c|c|c|c|c|c|c|c|c|c|c|c|}
\hline \multirow[t]{2}{*}{ No } & \multirow[t]{2}{*}{ Pernyataan } & \multicolumn{5}{|c|}{ Performance } & \multicolumn{5}{|c|}{ Expectasi } \\
\hline & & SB & $\mathrm{B}$ & $\mathrm{C}$ & TB & STB & SB & B & $\mathrm{C}$ & TB & STB \\
\hline \multirow{2}{*}{\multicolumn{12}{|c|}{$\begin{array}{l}\text { DS } 1 \text { Mendefinisikan Dan Mengelola Tingkat Jasa } \\
\text { DS 1.1 Rangka Pengelolaan Tingkat Jasa }\end{array}$}} \\
\hline & & & & & & & & & & & \\
\hline 1 & $\begin{array}{l}\text { Pelanggan mendapatkan pemahaman } \\
\text { yang jelas dari manajen bus antar kota }\end{array}$ & & & & & & & & & & \\
\hline 2 & $\begin{array}{l}\text { Bagaimana Pelayanan jasa bus antar kota } \\
\text { ter hadap pelanggan }\end{array}$ & & & & & & & & & & \\
\hline \multicolumn{12}{|c|}{ DS 1.2 Ketentuan Jasa } \\
\hline 1 & $\begin{array}{l}\text { Apakah ketentuan jasa dalam bus antar } \\
\text { kota sudah berjalan baik terhadap } \\
\text { pelanggan }\end{array}$ & & & & & & & & & & \\
\hline 2 & $\begin{array}{l}\text { Pihak bus antar kota mendasari } \\
\text { pelayanan yang berkarakter dan } \\
\text { memenuhi persaratan terhadap } \\
\text { pelanggan }\end{array}$ & & & & & & & & & & \\
\hline \multicolumn{12}{|c|}{ DS 1.3 Kesepakatan Tingkat Jasa (SLA) } \\
\hline 1 & $\begin{array}{l}\text { kesepakatan komitment pelanggan } \\
\text { dengan bus antar kota sudah optimal }\end{array}$ & & & & & & & & & & \\
\hline 2 & $\begin{array}{l}\text { peran dan tanggung jawab bus antar kota } \\
\text { sudah memenuhi standar yang berlaku }\end{array}$ & & & & & & & & & & \\
\hline \multicolumn{12}{|c|}{ DS 1.4 Kesepakatan Tingkat Pengoprasian (OLA) } \\
\hline 1 & $\begin{array}{l}\text { Apakah kesepakatan oprasional bus } \\
\text { antar kota sudah berjalan baik }\end{array}$ & & & & & & & & & & \\
\hline 2 & $\begin{array}{l}\text { Proses-proses pada layanan sudah di } \\
\text { sosialisasikan dengan jelas }\end{array}$ & & & & & & & & & & \\
\hline \multicolumn{12}{|c|}{ DS 1.5 Pemantauan dan Pelaporan Pencapaian SLA } \\
\hline 1 & $\begin{array}{l}\text { Manajemen melakukan pemantauan } \\
\text { terhadap bus antar kota }\end{array}$ & & & & & & & & & & \\
\hline 2 & $\begin{array}{l}\text { Manajemen melakukan pelaporan } \\
\text { terhadap pelanggan jika terjadi troble } \\
\text { dalam bus antar kota }\end{array}$ & & & & & & & & & & \\
\hline \multicolumn{12}{|c|}{ DS 1.6 Ulasan SLA dan Kontraknya } \\
\hline 1 & $\begin{array}{l}\text { Bus antar kota melakukan pelayanan } \\
\text { yang sesuai dengan yang di janjikan }\end{array}$ & & & & & & & & & & \\
\hline 2 & $\begin{array}{l}\text { Bus antar kota memenuhi semua yang di } \\
\text { paparkan saat perjanjian }\end{array}$ & & & & & & & & & & \\
\hline
\end{tabular}




\begin{tabular}{|c|c|c|c|c|c|c|c|c|c|c|c|}
\hline \multirow[t]{2}{*}{ No } & \multirow[t]{2}{*}{ Pernyataan } & \multicolumn{5}{|c|}{ Performance } & \multicolumn{5}{|c|}{ Expectasi } \\
\hline & & SB & B & C & TB & STB & SB & B & $\mathrm{C}$ & TB & STB \\
\hline \multirow{2}{*}{\multicolumn{12}{|c|}{$\begin{array}{l}\text { ME } 1 \text { Mengawasi DAN MENGEVALUASI KINERJA IT } \\
\text { ME 1.1 Pendekatan Pemantauan }\end{array}$}} \\
\hline & & & & & & & & & & & \\
\hline 1 & $\begin{array}{l}\text { Apakah pendekatan karyawan bus antar } \\
\text { kota terhadap pelanggan sudah baik }\end{array}$ & & & & & & & & & & \\
\hline 2 & $\begin{array}{l}\text { Apakah petugas bus antar kota bersikap } \\
\text { ramah terhadap pelanggan }\end{array}$ & & & & & & & & & & \\
\hline \multicolumn{12}{|c|}{ ME 1.2 Ketentuan dan kumpulan dari pemantauan data } \\
\hline 1 & $\begin{array}{l}\text { Standar bus antar kota sudah maksimal } \\
\text { terhadap pelanggan }\end{array}$ & & & & & & & & & & \\
\hline 2 & $\begin{array}{l}\text { Pelaporan data dalam bus antar kota } \\
\text { sudah berjalan dengan baik terhadap } \\
\text { pelanggan }\end{array}$ & & & & & & & & & & \\
\hline \multicolumn{12}{|c|}{ ME 1.3 Metode Pemantauan } \\
\hline 1 & $\begin{array}{l}\text { Apakah Metode yang diterapkan bus } \\
\text { antar kota sudah maksimal terhadap } \\
\text { pelanggan }\end{array}$ & & & & & & & & & & \\
\hline 2 & $\begin{array}{l}\text { Apakah Sistem yang berjalan dalam bus } \\
\text { antar kota sudah berjalan dengan baik }\end{array}$ & & & & & & & & & & \\
\hline \multicolumn{12}{|c|}{ ME 1.4 Pemeriksaan Kinerja } \\
\hline 1 & $\begin{array}{l}\text { Perbaikan Kinerja dalam bus antar kota } \\
\text { sudah maksimal terhadap pelanggan }\end{array}$ & & & & & & & & & & \\
\hline 2 & $\begin{array}{l}\text { Apakah perbaikan kinerja bus antar kota } \\
\text { berdampak baik terhadap pelanggan }\end{array}$ & & & & & & & & & & \\
\hline \multicolumn{12}{|c|}{ ME 1.5 Pelaporan Dewan dan Eksekutif } \\
\hline 1 & $\begin{array}{l}\text { Apakah laporan manajemen IT sudah di } \\
\text { sosilisasikan terhadap pelanggan }\end{array}$ & & & & & & & & & & \\
\hline 2 & $\begin{array}{l}\text { Apakah laporan anggaran bus antar kota } \\
\text { sudah sesuai dengan standar yang di } \\
\text { berikan }\end{array}$ & & & & & & & & & & \\
\hline \multicolumn{12}{|c|}{ ME 1.6 Tindakan Perbaikan } \\
\hline 1 & $\begin{array}{l}\text { pemantauan perbaikan terhadap divisi } \\
\text { bus antar kota meningkatkan } \\
\text { kenyamannan pelanggan }\end{array}$ & & & & & & & & & & \\
\hline 2 & $\begin{array}{l}\text { Apakah tindakan maintenance di divisi } \\
\text { bus antar kota sudah sesuai standar } \\
\text { yang diinginkan pelanggan }\end{array}$ & & & & & & & & & & \\
\hline
\end{tabular}




\section{BAB IV}

\section{Hasil}

REKAP HASIL KUESIONER

USER

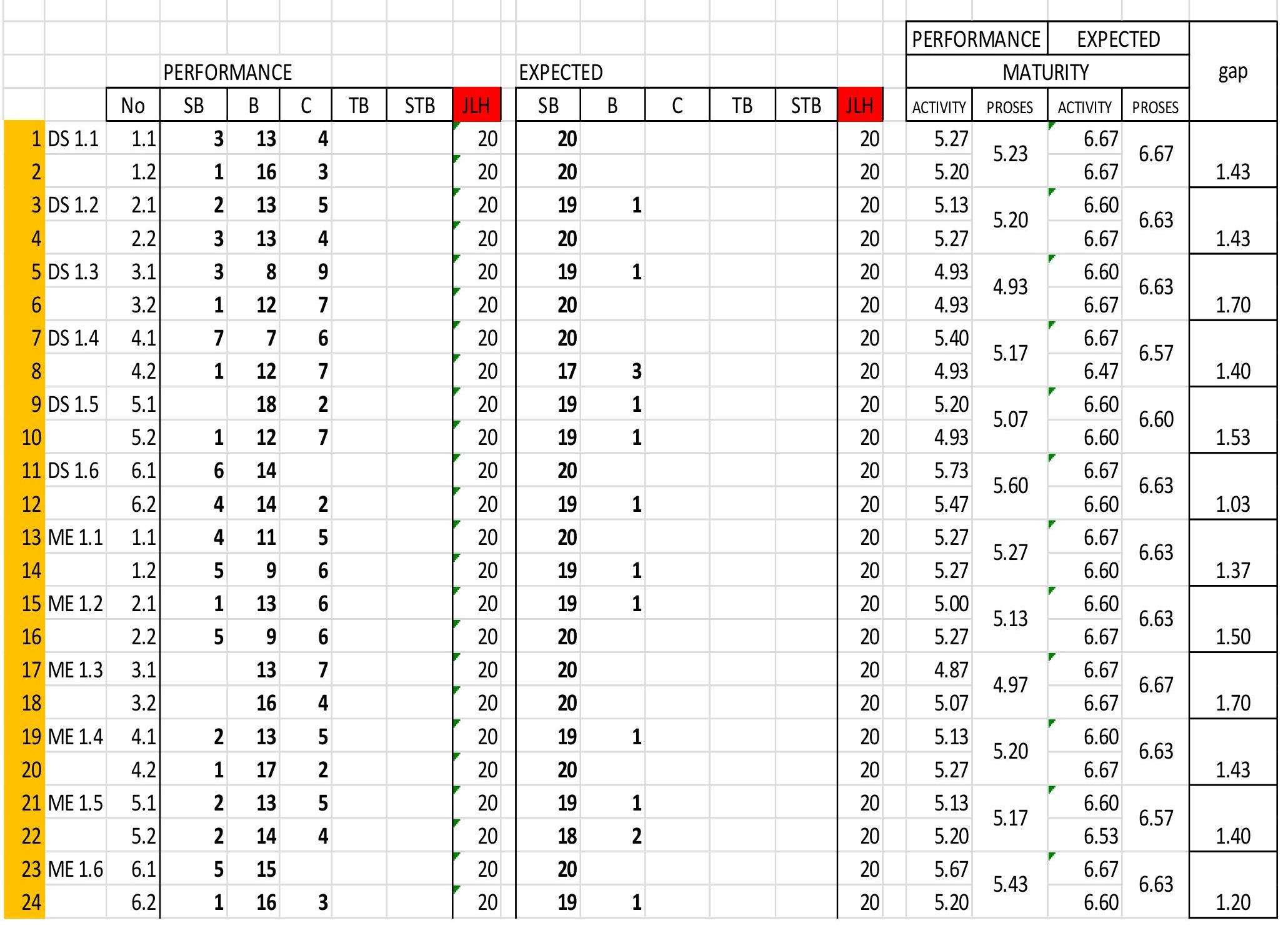




\begin{tabular}{|c|c|c|c|c|c|c|c|c|c|c|c|c|c|c|c|c|c|c|}
\hline & & & & & & & & & & & & & & PERFOR & MANCE & EXPEC & CTED & \\
\hline & & ERFOR & IANC & & & & & EXPECT & & & & & & & MATL & JRITY & & gap \\
\hline & No & SB & B & C & TB & STB & JLH & SB & B & C & TB & STB & JLH & ACTIVITY & PROSES & ACTIVITY & PROSES & \\
\hline 1 DS 1.1 & 1.1 & 5 & 2 & 1 & & & 8 & 8 & & & & & 8 & 7.20 & 750 & 8.00 & 800 & \\
\hline 2 & 1.2 & 7 & 1 & & & & 8 & 8 & & & & & 8 & 7.80 & 1.00 & 8.00 & 0.00 & 0.50 \\
\hline 3 DS 1.2 & 2.1 & 4 & 2 & 2 & & & 8 & 8 & & & & & 8 & 6.80 & 740 & 8.00 & 800 & \\
\hline 4 & 2.2 & 8 & & & & & 8 & 8 & & & & & 8 & 8.00 & & 8.00 & & 0.60 \\
\hline 5 DS 1.3 & 3.1 & 5 & 3 & & & & 8 & 8 & & & & & 8 & 7.40 & 770 & 8.00 & 800 & \\
\hline 6 & 3.2 & 8 & & & & & 8 & 8 & & & & & 8 & 8.00 & 1.10 & 8.00 & 0.00 & 0.30 \\
\hline 7 DS 1.4 & 4.1 & 7 & 1 & & & & 8 & 8 & & & & & 8 & 7.80 & 740 & 8.00 & 800 & \\
\hline 8 & 4.2 & 3 & 5 & & & & 8 & 8 & & & & & 8 & 7.00 & 1.40 & 8.00 & 0.00 & 0.60 \\
\hline 9 DS 1.5 & 5.1 & 5 & 3 & & & & 8 & 8 & & & & & 8 & 7.40 & 680 & 8.00 & 800 & \\
\hline 10 & 5.2 & 2 & 3 & 3 & & & 8 & 8 & & & & & 8 & 6.20 & & 8.00 & & 1.20 \\
\hline 11 DS 1.6 & 6.1 & 8 & & & & & 8 & 8 & & & & & 8 & 8.00 & 800 & 8.00 & 800 & \\
\hline 12 & 6.2 & 8 & & & & & 8 & 8 & & & & & 8 & 8.00 & .00 & 8.00 & 0.60 & 0.00 \\
\hline 13 ME 1.1 & 1.1 & 5 & 3 & & & & 8 & 8 & & & & & 8 & 7.40 & 730 & 8.00 & 800 & \\
\hline 14 & 1.2 & 3 & 5 & & & & 8 & 8 & & & & & 8 & 7.00 & $1 .<0$ & 8.00 & .00 & 0.80 \\
\hline 15 ME 1.2 & 2.1 & 5 & 3 & & & & 8 & 8 & & & & & 8 & 7.40 & 760 & 8.00 & 800 & \\
\hline 16 & 2.2 & 7 & 1 & & & & 8 & 8 & & & & & 8 & 7.80 & & 8.00 & & 0.40 \\
\hline 17 ME 1.3 & 3.1 & 4 & 4 & & & & 8 & 8 & & & & & 8 & 7.20 & 760 & 8.00 & 800 & \\
\hline 18 & 3.2 & 8 & & & & & 8 & 8 & & & & & 8 & 8.00 & & 8.00 & & 0.40 \\
\hline 19 ME 1.4 & 4.1 & 7 & 1 & & & & 8 & 8 & & & & & 8 & 7.80 & 780 & 8.00 & 800 & \\
\hline 20 & 4.2 & 7 & 1 & & & & 8 & 8 & & & & & 8 & 7.80 & 1.00 & 8.00 & 0.60 & 0.20 \\
\hline 21 ME 1.5 & 5.1 & 6 & 2 & & & & 8 & 8 & & & & & 8 & 7.60 & 740 & 8.00 & 800 & \\
\hline 22 & 5.2 & 4 & 4 & & & & 8 & 8 & & & & & 8 & 7.20 & & 8.00 & & 0.60 \\
\hline 23 ME 1.6 & 6.1 & 7 & 1 & & & & 8 & 8 & & & & & 8 & 7.80 & 790 & 8.00 & 800 & \\
\hline 24 & 6.2 & 8 & & & & & 8 & 8 & & & & & 8 & 8.00 & 1.50 & 8.00 & 0.00 & 0.10 \\
\hline
\end{tabular}




\begin{tabular}{|l|r|r|r|r|}
\hline & \multicolumn{2}{|c|}{ CURRENT } & \multicolumn{2}{c|}{ Expectacy } \\
\hline & USER & MGT & User & \multicolumn{1}{|c|}{ MGT } \\
\hline DS1.1 & 5.23 & 8.00 & 6.67 & 8.00 \\
\hline DS1.2 & 5.20 & 8.00 & 6.63 & 8.00 \\
\hline DS1.3 & 4.93 & 8.00 & 6.63 & 8.00 \\
\hline DS1.4 & 5.17 & 8.00 & 6.57 & 8.00 \\
\hline DS1.5 & 5.07 & 8.00 & 6.60 & 8.00 \\
\hline DS1.6 & 5.60 & 8.00 & 6.63 & 8.00 \\
\hline ME1.1 & 5.27 & 8.00 & 6.63 & 8.00 \\
\hline ME1.2 & 5.13 & 8.00 & 6.63 & 8.00 \\
\hline ME1.3 & 4.97 & 8.00 & 6.67 & 8.00 \\
\hline ME1.4 & 5.20 & 8.00 & 6.63 & 8.00 \\
\hline ME1.5 & 5.17 & 8.00 & 6.57 & 8.00 \\
\hline ME1.6 & 5.43 & 8.00 & 6.63 & 8.00 \\
\hline
\end{tabular}

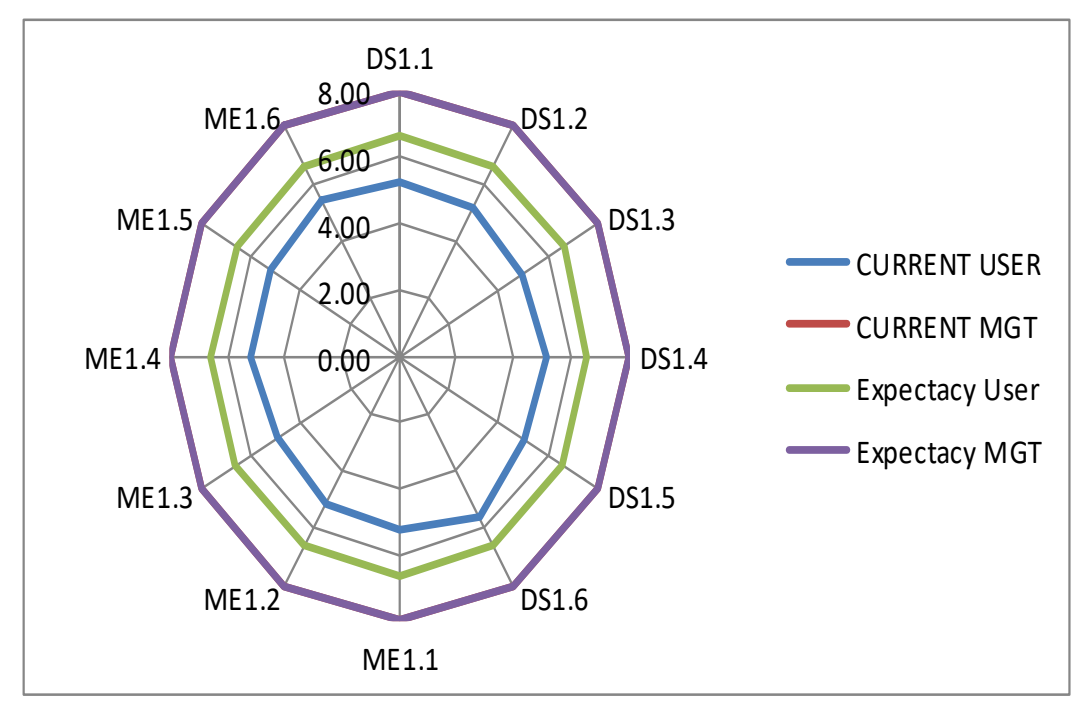

\begin{tabular}{|l|r|r|}
\hline & CURRENT & Expectacy \\
\hline US1.1 & 5.23 & User \\
\hline DS1.2 & 5.20 & 6.67 \\
\hline DS1.3 & 4.93 & 6.60 \\
\hline DS1.4 & 5.17 & 6.67 \\
\hline DS1.5 & 5.07 & 6.60 \\
\hline DS1.6 & 5.60 & 6.67 \\
\hline ME1.1 & 5.27 & 6.67 \\
\hline ME1.2 & 5.13 & 6.60 \\
\hline ME1.3 & 4.97 & 6.67 \\
\hline ME1.4 & 5.20 & 6.60 \\
\hline ME1.5 & 5.17 & 6.60 \\
\hline ME1.6 & 5.43 & 6.67 \\
\hline
\end{tabular}

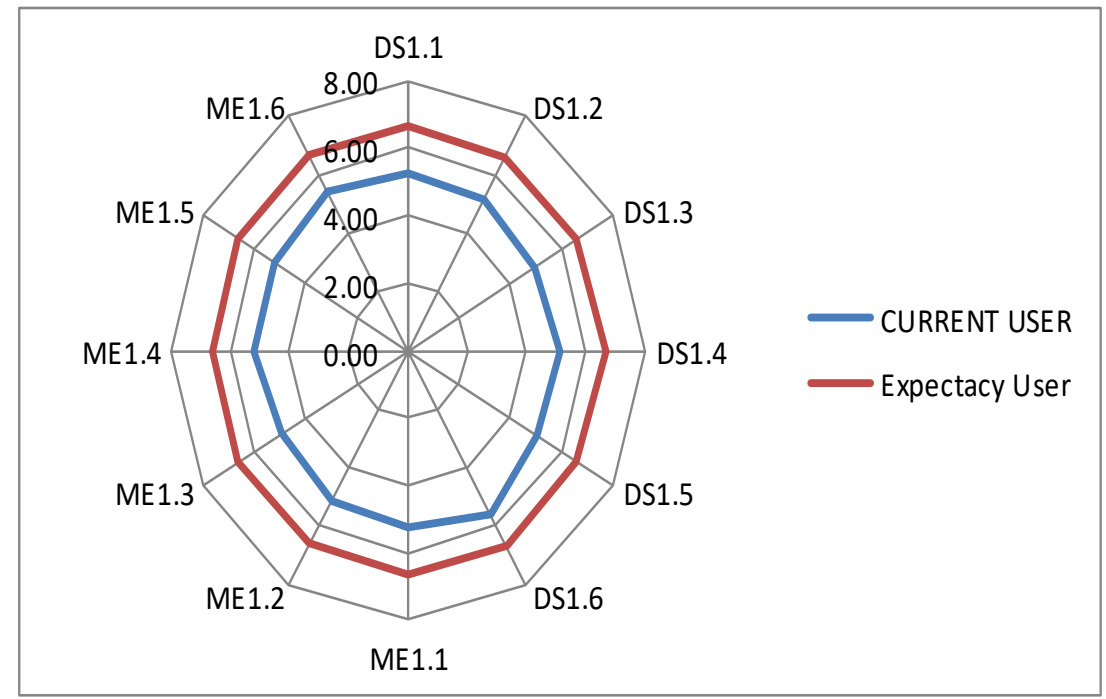

\begin{tabular}{|l|r|r|}
\hline & CURRENT & Expectacy \\
\hline MS1.1 & 8.00 & 8.00 \\
\hline DS1.2 & 8.00 & 8.00 \\
\hline DS1.3 & 8.00 & 8.00 \\
\hline DS1.4 & 8.00 & 8.00 \\
\hline DS1.5 & 8.00 & 8.00 \\
\hline DS1.6 & 8.00 & 8.00 \\
\hline ME1.1 & 8.00 & 8.00 \\
\hline ME1.2 & 8.00 & 8.00 \\
\hline ME1.3 & 8.00 & 8.00 \\
\hline ME1.4 & 8.00 & 8.00 \\
\hline ME1.5 & 8.00 & 8.00 \\
\hline ME1.6 & 8.00 & 8.00 \\
\hline
\end{tabular}

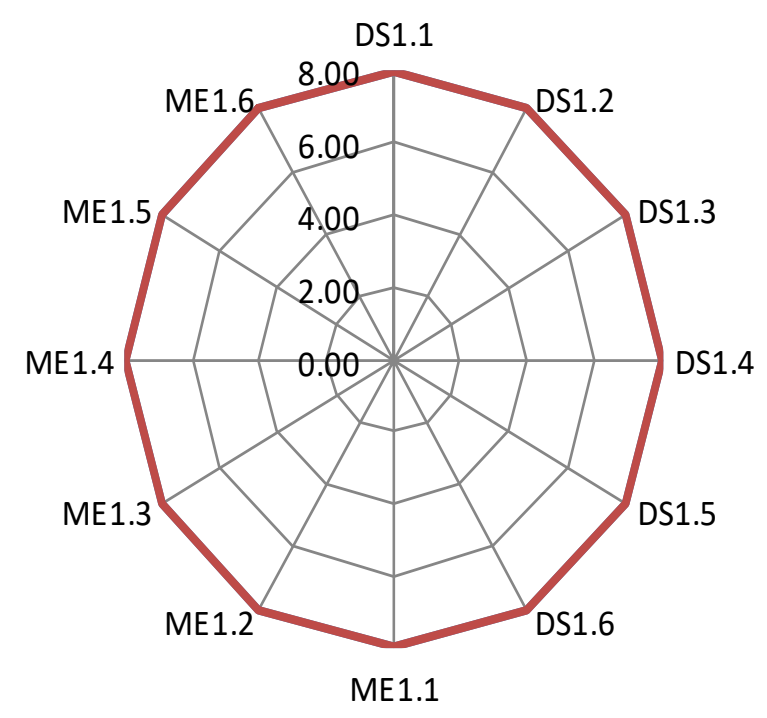

CURRENT MGT

Expectacy MGT 


\section{BAB V}

\section{Kesimpulan \& Saran}

Kesimpulan

Kesimpulan yang Penulis di dapat setelah melakukan audit adalah sebagai berikut :

- $\quad$ Tingkat malturity manajemen AKDP puspa jaya sudah sangat baik yaitu rata-rata maturitinya 7.40 yaitu sudah pada lvevel 5 Optimaize

- Tingkat maturity terhadap user di puspa jaya sudah sangat baik yaitu rata-rata maturity level 5.20 yaitu sudah pada lvevel 5 Optimaize

- Segala aspek dalam Bus AKDP Puspa Jaya baik itu rencana, maupun tujuan sudah berjalan dengan baik dan semestinya.

Saran

Beberapa saran yang untuk Puspa Jaya adalah :

- $\quad$ Tingkatkan lagi kenyamanan terhadap user agar kinerja yang sudah di capai akan menjadi lebih baik

- Manajemen Bus AKDP Puspa Jaya harus menjaga dan, meningkatkan kinerjanya agar menjadi lebih baik. 


\section{LAMPIRAN}
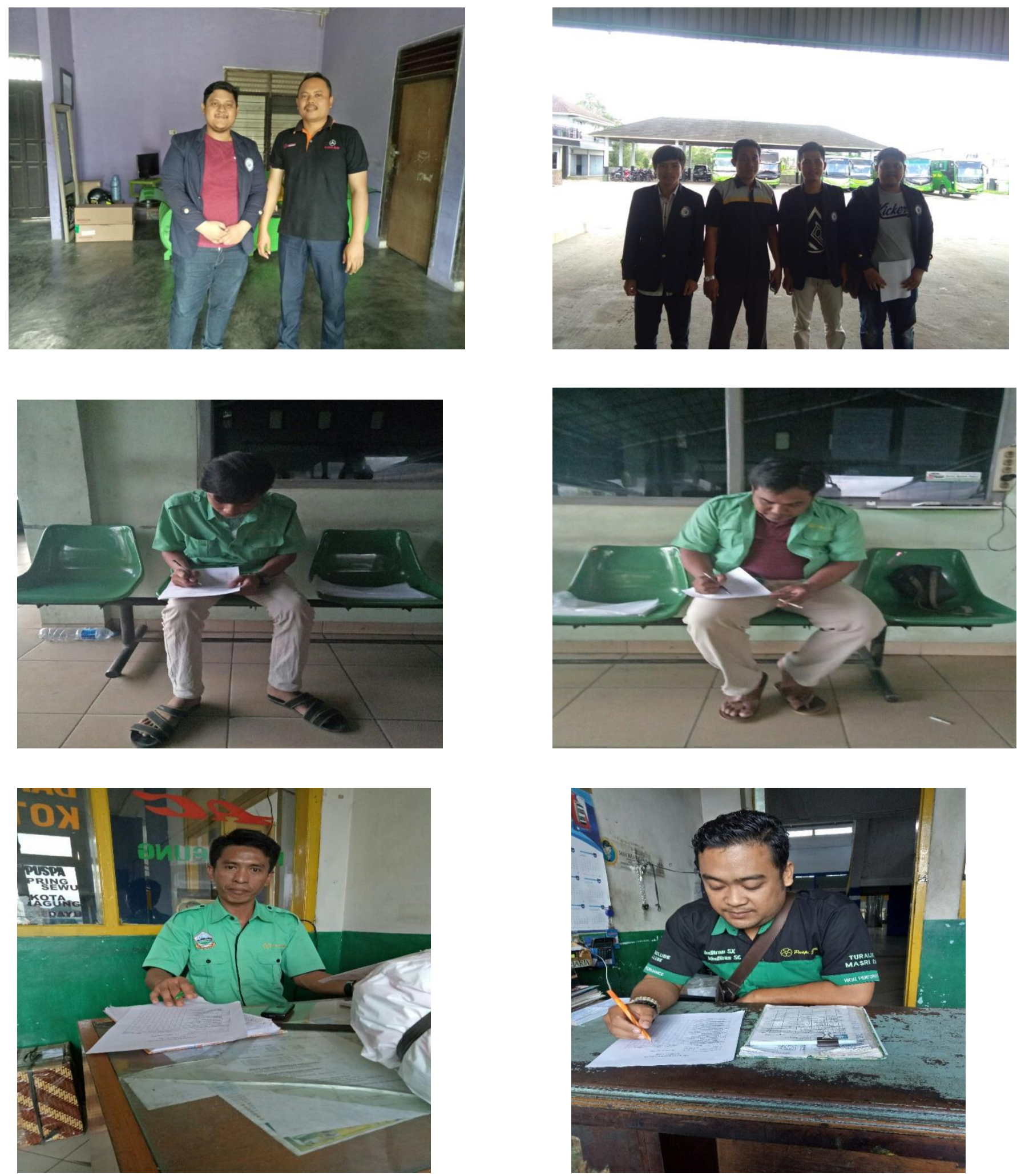

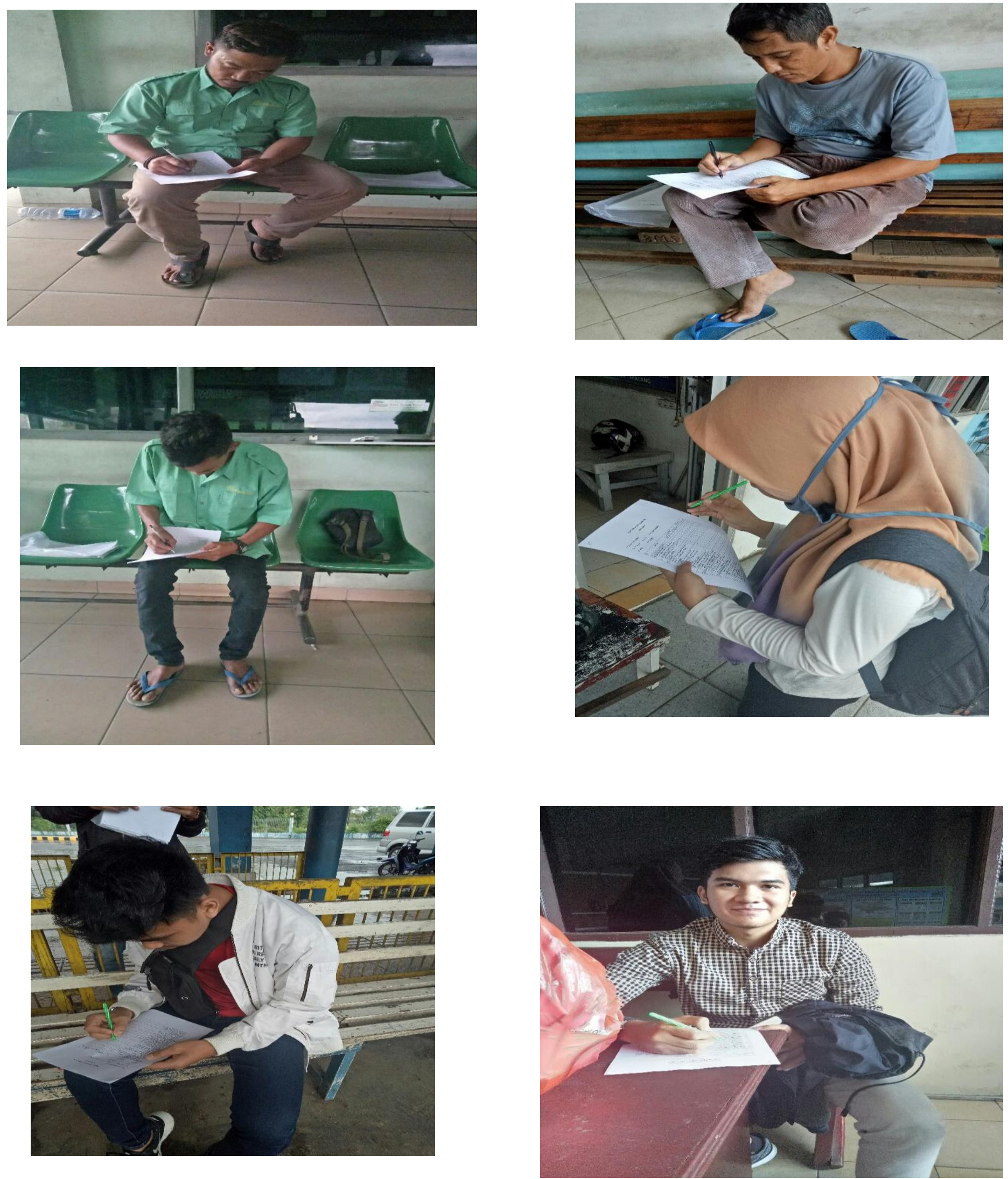

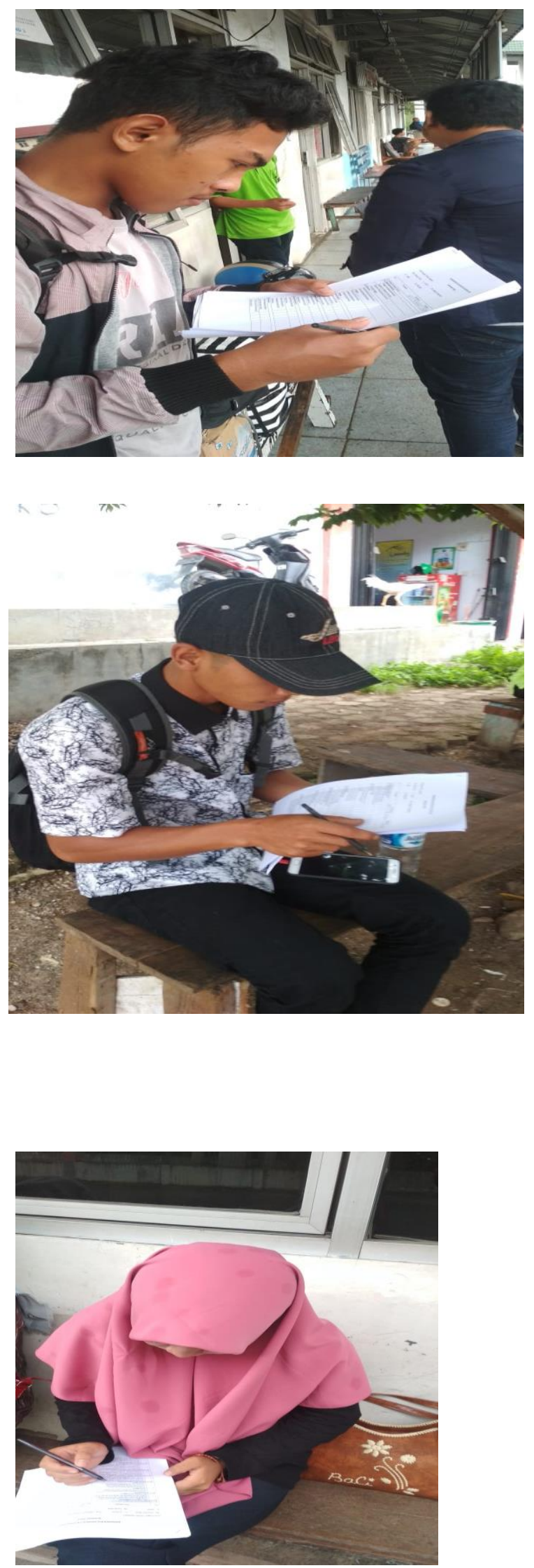
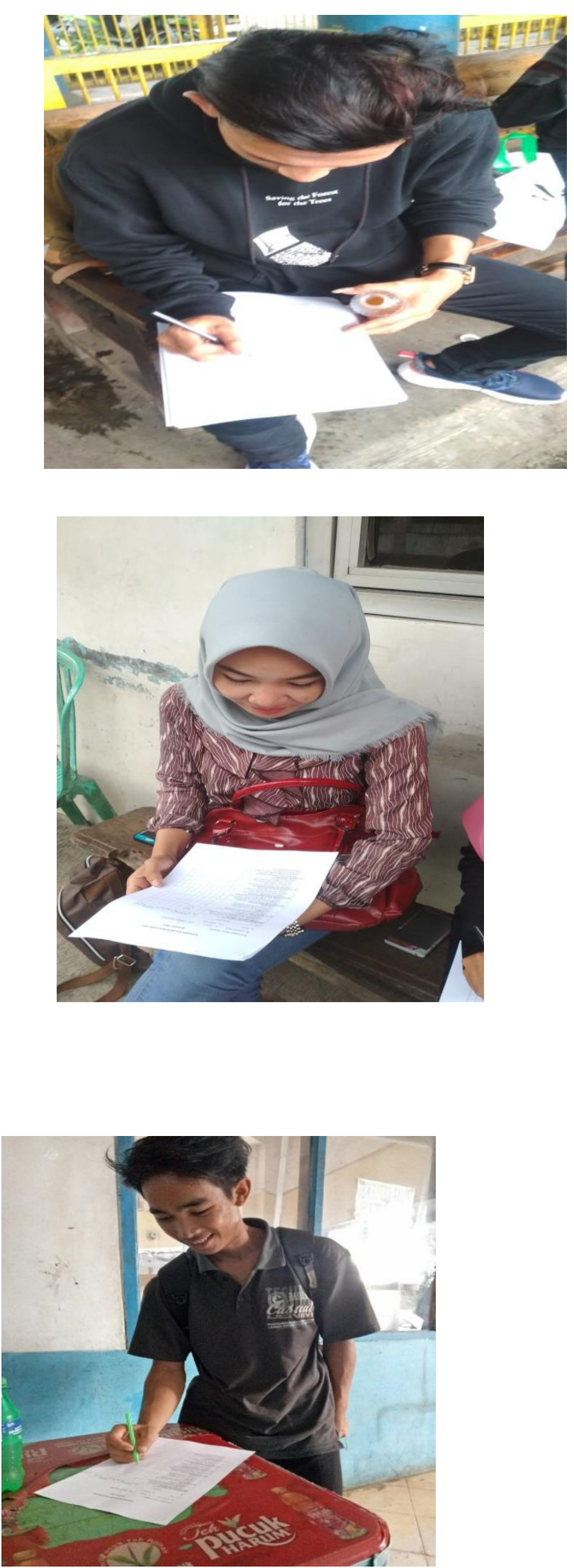

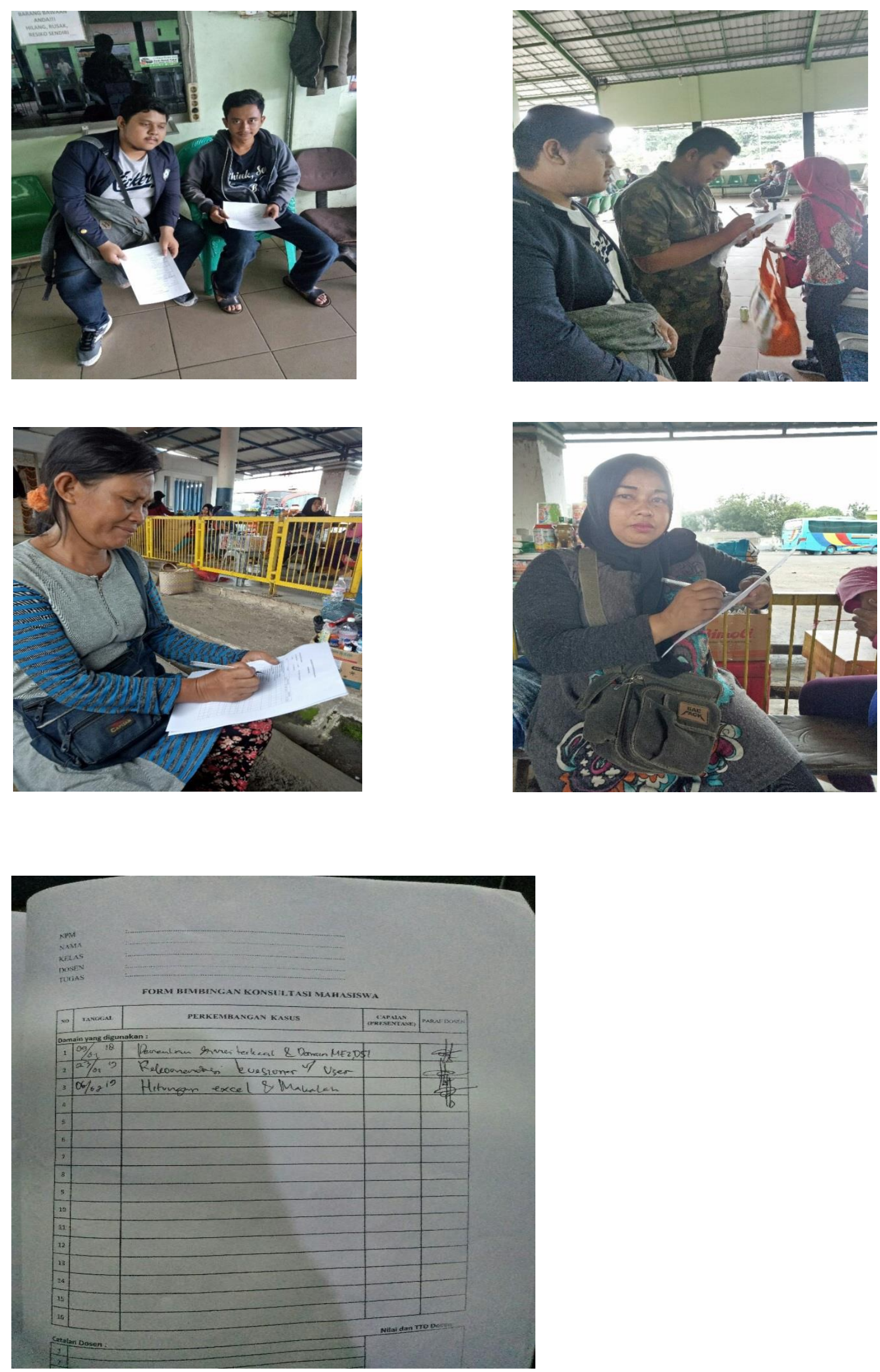